\title{
Grounded Theory Analysis of Work-based TVET and Intersectional Challenges Between Construction Workers'
}

\section{Marit Lensjø ${ }^{2}$}

Postdoctoral Fellow, OsloMet - Oslo Metropolitan University, Department of Vocational Teacher Education, Norway

\begin{abstract}
In this study, I examine training in the work-based part of Nonwegian technical vocational education and training (TVET). The TVET model includes two years in school followed by two years of apprenticeship at an authorized training enterprise. The empirical findings are based on one year of fieldwork combined with interviews, while following communities of plumbers and apprentices on construction sites and at a training agency. The article describes how work tasks and training on the construction site are continued and elaborated at the training agency, where technical theory and drawing are intertwined in practical plumbing. Over the past two decades, Norway has welcomed a significant number of eastern European migrant workers. Construction is among the industries most affected. This study explores how plumbers negotiate work and training at the intersection with dominant groups of foreign construction workers.
\end{abstract}

\section{KEYWORDS}

Apprenticeship / construction / plumbing / labor migration / organization of work / training agency / work-based TVET

\section{Introduction}

ocational education and training (VET) enjoys a high level of trust in Norwegian society, and more than a quarter of all Norwegian employees have a VET background (Steen et al. 2018). In 2019, nearly 30,000 training enterprises were authorized for apprenticeships, and more than 43,000 young students participated in the apprenticeship program (Norwegian Directorate for Education and Training 2020). The education program for building and construction is one of the core fields in Norwegian technical vocational education and training (TVET) in terms of crafts and traditions and of the number of students and training enterprises involved (Olsen et al. 2018). The Norwegian construction industry has been characterized as 'craft centered' and is associated with a considerable degree of worker autonomy and influence in decision-making (Eikeland 2015; Friberg \& Haakestad 2020; Reegård \& Rogstad 2019). The main goal of this study inspired by grounded theory is to explore training in the work-based part of Norwegian TVET. In this article, I analyze training and work in a community of plumbers at the construction site, and in a community of apprentices and a TVET-teacher at

\footnotetext{
${ }^{1}$ You can find this text and its DOI at https://tidsskrift.dk/njwls/index.

${ }^{2}$ Corresponding author: marlen@oslomet.no.
} 
a training agency. First, I discuss the collaboration between the training agency and membership training enterprises in the plumbing industry. Then, to investigate the learning environment at the workplace, I analyze the intersection between different groups of workers.

Unlike the school-based part, the work-based part of TVET is exposed to unpredictable factors and changes in the labor market. Large-scale labor migration is one such factor. Following the eastward expansion of the European Union (EU) in 2004 and 2007, Norway, like many other European countries, has experienced an influx of eastern European labor migrants. At most Norwegian construction sites today, large groups of labor migrants coexist with Norwegian skilled workers and apprentices. Few studies have examined how such coexistence operates in locations where sectors overlap, such as industry and education. TVET is one sector where the field of education intersects with the labor market and thus, lends itself to exploring the implications of this intersection. Although extensive labor migration has caused major changes in the construction industry, little research exists on how Norwegian skilled workers, apprentices and vocational teachers in work-based TVET are affected by these changes. Thus, this study is a step toward exploring how Norwegian training enterprises and training agencies conduct training, and how plumbers and apprentices negotiate craft-centered work in workplaces that are increasingly dominated by labor migrants.

The theoretical framework of this study falls within a classical account of situated learning and professional learning (Lave \& Wenger 1991; Schön 2001; Wenger 1998). However, in this literature, the individual's learning process is inextricably interrelated with the work-life setting, such as how plumbing is organized, negotiated and communicated on the construction site. The empirical findings build on rich field notes from one year of participant observations at one training agency and on one construction site, group interviews and in-depth interviews. With my own background as a plumber, TVET teacher and researcher, I used the opportunity to participate as a plumber in the community of plumbers and apprentices. From this work-along (Wadel 2016) insider position, I experienced much of the same reality as the study informants.

After the introduction, I present a background account of the Norwegian TVET model. Then, to describe the characterizes of labor migration in the Norwegian construction industry, in terms of work and workers, I present recent research on topics such as language barriers and the 'neo-Taylorist' management organization of work (Friberg \& Haakestad 2020; Kraft 2017). I then present the theoretical framework of situated learning, where questions of work and training are related to the community of practice and to the workplace (Lave \& Wenger 1991; Schön 2001). Thereafter, I introduce the methods used in field positioning and the mixed methods of data collection before I introduce the data analysis process. I then present results and show that alternation between 'real' work tasks in the community of plumbers, and relevant, intensive theory and practice at the training agency facilitates coherent training and learning. The results also reveal how language differences, different methods of organizing work and diverse work schedules on the construction site create irregularities in production, major delays and frustrations. Finally, I discuss the findings.

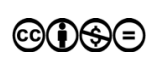




\section{Background}

Any attempt to understand learning at work has to consider the wider context in which a particular workplace exists. In the comparative literature on national skill formation systems, there is consensus that different training systems and the skills they promote have important economic and distribution effects. In the broad framework of varieties of capitalism (VoC), VET is one of the complementary institutions that distinguish the broad categories 'liberal market economies' from 'coordinated market economies' (Hall \& Soskice 2001). Several additional fine-grained typologies have been developed, examining cross-national equivalence in an attempt to create a nexus between the structure and the content of the training, how the training and work are regulated and organized, where the training takes place and the degree of involvement of the states and the firms in VET. Biernacki (1995) uses the term 'labour power' associated with the system in Germany, versus the term 'embodied labour' associated with the British system. Marsden (1999) distinguishes between a 'training' approach and a 'production' approach, while Brockmann et al. (2008) introduce the terms 'multi-dimensional competence-approach' versus 'the functionalist-behaviorist model'. To extend the qualitative differences within such terms, Clarke et al. (2013) introduce the concepts 'occupational capacity' and 'trade-based skills'. Strategies based on VET and occupational capacities could be adequate for the Norwegian model. However, none of the strategies described above are appropriate to cover the combinations of factors applicable to labor migration in the Norwegian construction industry: the disregard of VET-competence and the selected use of adult manual workers, - foreign-language speaking laborers organized into parallel societies, - temporary employment, fragmentation of work tasks and top-down management. This context is intimately linked to questions of managerial principles and techniques (especially Braverman 1977) confirming a revitalization of Taylorism in several aspects (Friberg \& Haakestad 2020). In this small study inspired by grounded theory, I focus on training in the work-based part of TVET, where plumbers and apprentices negotiate everyday work in the intersection between different groups of workers at the building site. I refer to the Norwegian communities as 'craft-centered' skilled work (Lave \& Wenger 1991) and to the foreign communities as 'neo-Taylorist' management organized work (Friberg \& Haakestad 2020).

\section{Norwegian upper secondary TVET}

All the Scandinavian VET models can be classified as cooperative. However, there are major differences between the Norwegian, Swedish and Danish systems (Nyen \& Tønder 2015). The Norwegian TVET model is based on two years in school followed by two years of apprenticeship at an authorized training enterprise. The high degree of general subjects in the school-based part of VET combined with the traditions of work-based apprenticeship training classify the Norwegian dual model as a hybrid of a state-based model and a corporatist model (Olsen et al. 2008). Generic competence, core values and interdisciplinary themes are central parts of VET throughout the $2+2$ education model (Core Curricula 2017; Ministry of Education 2019). In the intersection between different traditions of knowledge, Rauner (2004) argues that growth of personal and professional behavior is based on practical terms, and that competencies develop in 
confrontation with the task itself. The acceptance of practical knowledge, or knowhow, as a distinct form of knowledge emphasizes the importance of integrating workbased, practical vocational knowledge with formal knowledge. The multi-dimensional competence approach (Brockman et al. 2008) is based on a model of the active student and the employee taking an active role in constructing knowledge. Thus, competence is understood as the ability to deal with complex work situations, driven by multiple resources that the employee brings to the workplace (Rauner 2004). This understanding of competence is a holistic notion, relating to the whole person and including different dimensions (e.g., occupational, personal and interpersonal; Brockmann et al. 2008).

A Norwegian training enterprise is a public institution or a private company, which is authorized to conduct apprenticeship training. The enterprise is obligated to provide training according to national curricula. Several Norwegian plumbing companies intensify and secure apprenticeship training in cooperation with a training agency. A Norwegian training agency is a private enterprise, often run by vocational teaching staff, representing several member companies. Annual funding, following the apprenticeship contract, is used to finance the training agency's operations (Norwegian Directorate of Education and Training 2020).

\section{Labor migration in the Norwegian construction industry}

In 2004 and 2007, 10 central and eastern European countries were incorporated into the EU. Since then, millions of workers from the new member states have crossed borders. In most countries, construction has been one of the industries most affected. In 2003, 18,000 eastern European citizens were registered in Norway. By 2019, the number had increased to almost 216,500 (Statistics Norway 2019).

Most foreign migrants move for economic reasons such as better wages, better jobs and better working conditions (Cedefop 2011). However, few have any vocational education or training that can be considered comparable to a Norwegian craft or journeyman's certificate. Migrants' lack of language skills is one powerful barrier to integration and to labor-market success across Europe, and research shows that linguistic diversity causes systematic underutilization of immigrant worker skills (Cedefop 2011; Kraft 2017; OECD 2014). Professional values such as craft skills are undermined due to a lack of language and communication skills, and thus, migrant construction workers are generally regarded as unskilled in the Norwegian context (Alsos et al. 2016; Cedefop 2011; Kraft 2017).

Different forms of nonstandard employment arrangements, such as part-time employment, fixed-term employment and self-employment, have coexisted for centuries, also in the Nordic countries. However, the 'standard employment relationships' based on full-time open-ended contracts have become the very foundation of most Nordic welfare and market institutions (Ilsøe et al. 2019; Kalleberg 2000). According to Ilsøe et al. (2019), this foundation has recently been challenged by the growth in new ways of organizing work. A wide range of non-standard work and employment conditions exist, such as zero-hour contracts, short-term contracts, temporary agency work and shift work (Friberg 2016; Ryan et al. 2019). A network of staffing agencies, subcontractors and temporary work agencies has developed since 2004. The sudden, inexhaustible access to migrant labor, changed the Norwegian construction industry from being an industry

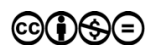


largely based on permanent employment and so-called 'accord' work (Friberg \& Haakestad 2020), to becoming the largest employer of temporary workers (Ødegård et al. 2012). Foreign language-speaking, temporary employees required more managementled organization of work, and the consequence leads to a fragmented building process. Friberg and Haakestad's (2020) study showed that the comprehensive use of temporary workers was, deeply linked to the deconstruction of skilled, craft-centered work and the introduction of neo-Taylorist management principles and precarious working conditions in the Norwegian construction industry.

\section{Situated work-based learning}

The most important features of construction work are the non-standardization of products and the worker's capacity to combine broad knowledge of materials, tools and procedures with manual dexterity, acquired through extensive training (Dreyfus \& Dreyfus 2012; Schön 2001; Sennett 2009; Stinchcombe 1959). To maintain the heritage and infrastructure of existing buildings, and at the same time, respond to the complexity of new building structures and progress schedules, the construction industry depends on many types of professional knowledge, competencies and experience. The nature and meaning of the work environment have always been essential to becoming a craftsman. The craftsman's work and learning environment consists of materials and tools, location, work task and most of all, the social and professional community of skilled workers in the community of practice (Lave \& Wenger 1991). As participants in the work process, apprentices are guided and instructed in what goes on in their own practice and gradually, become independent and skilled workers (Lave \& Wenger 1991; Nielsen \& Kvale 1999; Wenger 1998). As an aspect of social practice, apprentices invest their whole selves in the social community and their wide systems of meaningful relations. These specific systems of relations occur are reproduced and developed in social communities, which means the relations not only define learning as a vocation but also construct an identity (Lave \& Wenger 1991). When Schön (2001) claims that 'our knowledge is in our actions', he refers to how our senses and behavior respond to the situation and the materials we deal with in everyday life.

Similar to Lave and Wenger (1991), Illeris $(2006,2010)$ argues that all learning is situated. This relates to interaction between human beings and the context they create or the work they produce. In addition, the utility and purposes of all tools are implemented by human beings and result from their ideas about how they can be used, meaning that interaction with the material world cannot be understood differently from interaction with the social world. Becoming a competent plumber, however, takes more than just being part of an environment. Illeris $(2006,2010)$ claims that learning implies two very different processes; external interaction between the learning and the individual's social, cultural and material environment and an internal psychological process of elaboration and acquisition (Illeris 2006, 2010).

Through situated learning in a community of practice, students and apprentices gradually acquire skills and knowledge about their new world (Dreyfus \& Dreyfus 2012; Lave \& Wenger 1991; Wenger 1998). One way to understand situated workplace learning is to see it as a fostering process, the purpose of which is to pursue a certain profession. Another way to understand situated learning is to consider what is learned 
as belonging in a specific context. Brown et al. (1989, p. 4) explain this in a simple way: 'It is quite possible to acquire a tool but to be unable to use it'. VET-teachers and skilled workers in communities of practice build an increasingly rich understanding based on the experienced competence of former craftsmen. Understanding how to use plumber tools to build a pipe system, is an example of the cumulative wisdom of the culture in which the tools are used and where the meaning is a product of negotiation within a culture and of practice in authentic activity.

\section{Methods and data}

\section{Fieldwork and field positioning}

This study takes an ethnographic approach, based on a combination of fieldwork and interviews with apprentices, plumbers and a vocational teacher. My field notes are based on about 450 hours of participant observations from one construction site in Oslo and from one training agency. During the fieldwork, I conducted group interviews and informal conversations with the manager and the foreman, the plumbers and the apprentices. At the end of the fieldwork, I conducted in-depth interviews with the plumbers, the apprentices and the vocational teacher. One plumbing manager and one foreman, eleven plumbers and four apprentices worked on the construction site. They were all employed at the same company. The apprentices worked at the plumbing company four days a week, with one day reserved for training at the training agency. Nine first-year apprentices receive training at the training agency, which is run by a plumbing vocational teacher.

To answer the research questions, I needed a wide range of data from learning situations, observations and descriptions of the senses and the body, the meaning of professional language and tacit knowledge, situated to central work tasks and in touch with materials and tools. The combination of my close observations and the informants' voices from the interviews could give me multifaceted data different from any other methodological approach. As a former plumber and a vocational teacher, I was able to 'enter the landscape of practice' (Nielsen \& Kvale 1999), dressing and working as a plumber during my fieldwork. Within our own culture, there exists, what Giddens (1993) calls 'a mutual knowledge', meaning that the researcher is able to take advantage of the professional and cultural knowledge he or she shares with those observed experiences (Wadel 2016). Within the community of plumbers, I followed the group during their morning meetings, coffee and lunch breaks and all the steps of training and plumbing. From this unique position, I was able to observe the informants in and out of work and training. The otherness of the fieldworker in an institutional workplace such as a health institution or a construction site, where all the workers occupy a certain professional role and position, is obvious. According to Van der Geest and Sarkodie (1998), qualitative researchers in an institution, such as a hospital or clinic, find themselves out of place. Being neither a doctor, nurse or other type of health worker nor a patient makes their position somewhat awkward. It is currently more common for fieldworkers to engage in participant research, working alongside or dressing like and following professionals (Agrosino \& Mays de Pères 2000; Hastrup 2010; Ringer 2013; Wadel 2016).

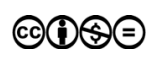


At the training agency, I had a relatively passive position, especially during the teaching sessions. During the practical work tasks, it was easier to walk between the groups, observe and listen to discussions and talk spontaneously with the apprentices. Before each session, the TVET teacher informed me about the plan, and during the breaks and after each session, we reflected on the tasks, materials and training. After a while, the teacher understood what I was looking for, and what questions I was particularly interested in. The teacher turned out to be a key informant and could indicate situations or incidents concerning the apprentices or the training.

\section{Field notes and interviews}

After each observation period, I conducted interviews with the plumbers, the TVET teacher and the apprentices. The interviews were based on an interview guide, focusing on central themes like the importance of responsibility, involvement of the senses, using the body, language, tools and materials, participation in the community, role models, theory and practice, independence and milestones. The fact that I had worked with the informants in the field made the interviews natural and more like a social conversation. My questions were often introduced by depicting a specific situation on the site. With this as a starting point, I encouraged the informants to describe their own reactions, thoughts, ideas, feelings and experiences until they had nothing more to add. I made sure that all the topics in my interview guide were discussed. The interviews were recorded and later transcribed. Reading through this comprehensive text material, I discovered the differences between my descriptive and detailed field notes, and the voluminous, though less precise, language in the transcribed interviews. The transcribed interviews, on one hand, consisted of 'raw' data, shaped by the informants' spontaneous reactions during the interviews, and by their personal experiences and expectations. My field notes, on the other hand, were already condensed and analyzed several times, first. In the situation as a fieldworker, observing and capturing the specific situation in a bullet point or brief sentence in my notebook. I understood much later that this spontaneous analysis was undoubtedly an important step in my analysis. Second, on my way home from the field, I was able to reflect on each situation individually, as well as relate them to each other. Third, back home, another important analysis took place in the retrospective process of reconstructing the brief bullet points or sentences written down in my notebook into 'thick' descriptions (Geertz 1973).

\section{Ethical considerations}

This project was evaluated by the Norwegian Data Protection Service (NSD). Before the study began, the informants received an information letter in which I described the focus of the study. In the letter, and later in a meeting, they were informed about my participation at the building site and at the training agency, how I intended to observe them, to write field notes and to conduct interviews. I explained how I planned to store and anonymize the data, and how I planned to publish the results. All participation in the project was voluntary, and the informants were able to withdraw at any time without negative consequences. Before the data collection started, all informants signed a consent form, accepting their participation. 


\section{Limitations}

I did not interview migrant workers. If I had, this study would present a more nuanced picture of the migrants' role and of the interaction between the groups. Although the labor migrants in this article are referred to as a collective group, construction workers from several nations were at the sites. The migrants represented different forms of employment, different languages and different occupations, but the majority consisted of eastern Europeans who worked in a permanent rotation system.

\section{Analysis}

The data collection, reflections and analysis in the study were inspired by grounded theory (Glaser \& Strauss 1967). My goal as a researcher is to be true to the study subjects and thus, to 'study experience from the standpoint of those who live it' (Charmaz 2014, p. 403). I used an inductive approach during the data collection and the text analysis (Alvesson \& Sköldberg 2005; Charmaz 2014; Corbin \& Strauss 1990; Glaser \& Strauss 2008). I started the process of text analysis by coding sentence by sentence. To prevent the meaning content from being lost due to fragmentation of the whole, I realized that it also was relevant to code incident by incident, and sometimes, even situation by situation. I organized the data into a comprehensive data set in order to analyze and compare text in my field notes with text in the transcribed interviews. I wanted not only to compare multifaceted data but also to unify and expand the categories in my field notes with tacit information such as the informants' thoughts and feelings expressed in the interviews. As I moved back and forth in the texts, analyzing and comparing cross-sectional codes and searching for patterns or underlying structures, different texts steadily grew into rich and multifaceted categories based on empirical data. The main categories are driving forces, responsibility, success and defeat, self-confidence, body and independence, active learning, time and volume, participation and interaction, organization of work, linguistic and occupational differences and production logics.

\section{An unexpected grounded theory outcome}

As a newcomer on the construction site, it took a while before I noticed the tensions between the smaller community of Norwegian plumbers and the larger community of labor migrants. An unexpected episode suddenly shifted the focus to the intersection between the groups. In the reflective process between existing theory and the researcher's pre-understanding, 'abduction can involve a kind of hermeneutic spiral: an interpretation of facts of which we already have a certain preconception' (Alvesson \& Sköldberg 2005, p. 59). Inspired by Gluckman's (1959) empirical investigation of social conflicts, I used his method of 'scrutinizing particular situations of conflicts as complexes of connected incidents that were occurring in the field, in order to isolate and identify the actual mechanisms underlaying the development of the conflict' (Evens \& Handelman 2005 , p. 2). To understand and interpret my own data material, I turned to research on labor migration in the Norwegian construction industry (Friberg 2012, 2016; Friberg \& Haakestad 2020; Kraft 2017). 
The approach to hermeneutics explains how I moved back and forth between the data material, the literature and my own pre-understanding in order to recognize possible patterns and structures. This means that my understanding of theory, my preconceptions and my interpretations of the data material influenced the empirical results. No computer programs or transcription tools were used during the analysis of the comprehensive text material. The researcher's involvement and interpretations shape the direction of the study, which constitute the very core of grounded theory analysis (Charmaz 2014).

\section{Results}

The results are presented in two sections. The first section includes learning and training at the construction site and at the training agency. The second section concerns work and collaboration at the intersection between migrant workers and the community of plumbers on the construction site.

\section{Apprenticeship}

\section{Conditions at the training agency}

The training agency consisted of one classroom, a large two-story workshop, two storage rooms for tools and materials and an office for interviews and administration work. The staff consisted of one TVET teacher and one assistant. The teacher was also the manager of the agency and was responsible for the training. Both were full-time agency employees. The agency also hired external trainers, such as in welding and certification courses. In addition to his teaching tasks, the TVET teacher joined several networks and organized the extensive logistics of the training agency.

\section{Learning content and training at the training agency}

In preparation for the apprenticeship, the training agency arranged an orientation week. The apprentices were introduced to plumbing theory and practice and started to plan, and then build, a bathroom. They began by drawing a room with windows and a door on a 1:20 scale and discussed where to install the sanitation equipment. When the drawing was finished, they brought their plan into the workshop and began drawing the installations on the floor, on a 1:1 scale. As they stood in their imaginary 1:1 scale bathroom, several conflict areas emerged: It was not possible open the door, the toilet was too close to the wall and impossible to use, and the shower covered the window. They returned to the drawing board to revise the plan. The second time, they scrolled through the textbook, searching for guidelines on the positioning of sanitation equipment to help them plan a bathroom that was feasible and in accordance with the regulations. In this process of moving back and forth between the workshop and the classroom, the apprentices discovered important connections between theory and practice. The apprentices worked in groups, and the teacher moved from one group to the next, discussing and 
listening to the apprentices' arguments. When the bathroom drawing was revised, still in 1:1 scale, on the floor in the workshop, the apprentices drew the sewage pipes on the floor. Then, they fetched pipes and fittings from the storage room and began to lay the pipes, according to the lines they had drawn on the floor. They soon realized that it was impossible to lay the pipes in the way they had drawn on the floor, and again referred to the textbook, made new calculations, had discussions and created a new drawing. During the process, the teacher asked questions to make them stop and reflect, such as 'Why like this, and not like that?':

Here at the training agency, the drawing and the theory is close to the practice in the workshop. We use tables, calculate water volumes, dimensions and drainpipe gravity, we construct sanitation drawings and calculate different scales, so ... a lot of math. Often, the teacher joins us and asks questions: "What is the name of this symbol, or this part?," "What functions does it have?," and "Why is it placed exactly there?" Explaining to others what I do and why, I think it's a good way to learn. Often, the teacher points out things we do in the workshop. Then he explains. Next time, he asks one of us, or he repeats. (Apprentice)

During the orientation week, the teacher always tried to involve the apprentices, encouraging them to talk about real work tasks on the construction site, and about their relationships with the plumbers. He listened carefully and asked follow-up questions. Through these brief conversations, he gained an understanding of the apprentices' learning prerequisites and the learning conditions and work environment in the training enterprise. He said:

Involving the apprentices is important. It's important to let them explain things, both professionally and socially. One purpose is to capture gaps in their professional understanding, so I can understand what they need. Another, of course, is to ask if they are okay. The best training enterprises are those that give positive and relevant feedback. Good feedback is a boost to the learning process.

Organized in groups, the apprentices discussed different ways to plan and solve every step of the tasks. Together with the teacher, they calculated and dimensioned the pipes and parts, converted the pipe systems into technical drawings, made material lists and did the plumbing. During my observations, it was obvious that the concepts and plumbing rationale became an increasingly important part of the apprentices' language and discussions:

We talk about what we do and about plumbing on the construction site as well, but here at the training agency it's more intense. The teacher asks again and again. All the cramming and the repetitions, ... Sometimes it's tiring. But ... we learn a lot that way. That's pretty good actually (Apprentice)

After the orientation week, the apprentices continued their training at the training agency one day a week. After the first elementary project, they were introduced to increasingly complex sanitation and heating projects. Step by step, they linked theory, technical 
drawing and practice together. Plumbing involves a comprehensive range of materials. Plastics, brass, copper, cast iron and steel are used to distribute various media. Water and wastewater, heating water or glycol have different properties and functions and require different pipe systems. Each pipe system comes with a large number of fittings. Knowing the differences between parts and dimensions, and being able to select, use and learn the names of the parts, is a time consuming and difficult process. An informant stated:

Often, I know what to do, but don't remember the words. Sometimes, I just study the parts, feel them in my hands, put them together and take them apart. It's difficult to tell the difference between them and to remember the names.

\section{Conditions at the construction site}

The construction site I followed during my fieldwork was the largest in Oslo at the time. The plumbers' main tool storage space was two containers located between the buildings. The main storage space for pipes and fittings was in the technical room, with easy access from the parking lot to all the buildings. In addition, the plumbers established small storage units for pipes and fittings in each building. These storage units were close to their daily work and contained the tools and pipes needed for the next day or two. The community of plumbers and apprentices on this construction site, built technical rooms and pipe systems for radiators and underfloor heating, water and wastewater systems, wet pipe fire sprinkler systems, snow melting systems and underground main water and sewage installations.

\section{Learning content and training at the construction site}

It takes time for newcomers to get to know colleges, learn how to operate the building elevator or to find the construction office, the temporary barracks with site facilities and all the different storage units on the construction site. During the first months, I observed that the apprentices often worked alone. They were responsible for minor, repetitive tasks, such as drilling, hammering or unpacking and carrying equipment such as materials and tools. Although such jobs could be tedious, the apprentices enjoyed having the freedom to plan their own work and work tasks. Working alone made them more concentrated in every step of work and with routines and rules at the construction site. While the apprentices worked alone, the plumbers were able to observe and evaluate their performance. When the apprentices did any plumbing, it was often in close collaboration with the plumbers. One obvious criterion in all kinds of plumbing is to avoid leaks and potential water damage, so the plumbers were responsible for their own work as well as for that of the apprentices. Working alongside each other, the plumbers were able to observe the apprentices, guiding and correcting them or showing them how to do tasks. In the beginning, the apprentices needed assistance in every step: measuring, marking and attaching wall or ceiling brackets, cutting pipes, selecting the right fittings and threading, soldering or screwing the parts together. It was easy to observe how their fingers and hands gradually achieved the correct results. Alongside the plumbers, the apprentices concentrated on their own work but were able to watch how the plumbers 
moved, used their hands and fingers, applied hemp on a thread, and how they measured and marked their work. In the interviews, all the apprentices agreed that working alongside the plumbers was the most positive learning situation, assuming two factors: The first factor was that the plumbers must allow the apprentices to investigate and to think while doing the job, allowing the apprentices to feel and hold the parts in their hands, to study them from different angles, and to make mistakes and try again. This was timeconsuming, but important for understanding how and why things were connected. The second factor was related to the plumbers' ability to make the apprentices feel safe and accepted as novices. If the interaction with the plumbers consisted of yelling, anger or sarcasm, the apprentices did what they were told but without understanding what they were doing or why. In such cases, they concentrated entirely on following instructions and avoiding reprimands. One of the apprentices explained:

'He [the plumber] is so angry, and it makes me insecure about everything. ... I can't ask the same thing over again, because if I do, he gets mad and screams, "I've already told you!" And if I do something wrong, he shouts, and when he yells at me, I get even more insecure. When I'm with him, I'm afraid to try out anything. I just wait for him to tell me what to do and try to remember everything he says.

The plumbers and apprentices spent much of their day together. They often traveled together to and from work, attended morning meetings and took coffee and lunch breaks together. Some days, the plumbers and apprentices worked together on the same task, for hours. By drawing sketches and discussing plumbing tasks in and out of work and situations, the plumbers shared their experience and developed the apprentices' knowledge of materials, systems, tools and the rationale. In the interviews, the plumbers emphasized the importance of developing professional knowledge:

If you're a skilled worker and keep up to date on professional knowledge, you can discuss your profession with anyone, the architect, the construction manager or the customer. Being able to influence your own work is important. It makes a difference. If you are treated like a professional in the workplace, then you gain self-confidence. That means a lot for job satisfaction and for who you are as a person. (Plumber)

During lunch and coffee breaks, the plumbers often discussed the use of equipment or the latest news in plumbing, such as articles in trade magazines, manuals or suppliers' websites, as well as politics, such the U.S. election, current affairs, family matters, taxes and wages.

\section{Collaboration on the construction site}

Every building consists of millions of small and large construction parts. Constructing a building is a comprehensive logistical process. Every part must be fitted in the right place at the right time. Collaboration is essential to ensure progress, quality and security. During my fieldwork, I observed that communication between the Norwegian and foreign construction workers was difficult both ways. Without a common language, much of the communication consisted of body language and a mix of English, Norwegian and Polish or Lithuanian or none at all.

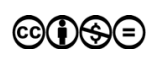


The most striking differences between the Norwegian and foreign construction workers on the site were the linguistic diversity and the work hours. The foreign construction workers worked a permanent rotation system based on three-week periods. Thus, they worked 10-12 hours, six days a week for three weeks in a row. Then they were replaced by a new group. Due to the migrant workers' long work hours, the construction time was significantly shortened. Because the Norwegian plumbers worked the standard 37.5-hour week, large parts of the production were continued or completed without the necessary collaboration between the construction workers involved in the same progress. During my fieldwork, I observed several misunderstandings and delays caused directly or indirectly by the mismatched work-schedules. In addition, language barriers blocked several attempts at collaboration, and contributed to a constant imbalance in the progress. In the Norwegian group, the lack of collaboration led to more work, delays and frustrations.

During my fieldwork, I observed that some of the plumbers were laying water and sewer pipes under the second-floor deck, in preparation for sanitation equipment on the floor above. The soil pipes and parts were large, heavy and difficult to handle up and down the ladders. Along with other technical installers, the plumbers had worked halfway through the first floor when, one morning, they found that the ceiling had been sealed. A large group of foreign workers had installed ceilings the previous night, erecting metal frames and plasterboard under the existing second floor. Alone on the construction site, the large group of migrant subcontractors worked without interruption and were able to build the ceiling extremely fast. The next day, the ceiling posed a major problem for the technical workers who had to remove the plasterboard and carefully crawl through the metal frames in the sunken ceiling, in order to complete their installations. Building the sewer system suddenly turned into a complex and extremely time-consuming job. The entire group of plumbers, electricians and ventilation technicians was frustrated when they confronted the site manager. Long discussions about the ceiling and the progress did not seem to provide any quick solutions. The ceiling workers were all gone, and while the managers argued, the real problem was left to the plumbers and the other technical installers. A plumber said: 'Listen, this happens all the time. When you leave the construction site on Friday, you never know what it will look like on Monday'. In the interviews, it became clear that differing organization of work and lack of collaboration caused frustration among the plumbers:

If plumbers, carpenters and painters cooperate on everyday work, it's possible to make adjustments and improvements as well as discover or prevent conflicts there and then. But to temporary workers and the main group of migrant workers, it seems to be more important to deliver just the exact piece of work than to build a house. Every week, we're stuck with delays, arguments and substandard work. Much of the working environment and the job satisfaction disappear. (Plumber)

\section{Discussion}

\section{Learning content and training}

The orientation week at the training agency was intensive preparation for performing key plumbing tasks. The initial step-by-step task provided a breakthrough for the apprentices' 
understanding of the coherence between theory and practice, and between sketches and drawing. These findings are in line with Rauner's (2004) argument that competences develop in confrontation with the task itself. The analysis of the data from the training agency and the construction site showed that communication and interaction were essential at all stages of working and learning. Discussions and reflections on planning and doing with fellow apprentices, the TVET teacher and the plumbers provided opportunities to exchange experience and compare different ways of performing the tasks. Communication also meant opportunities to resolve unforeseen challenges, correct plans and thus avoid errors or delays. According to Brown et al. (1989), people who use tools and materials build an increasingly rich implicit understanding of the world in which the tools are used, and of the tools and materials themselves. Accordingly, the plumbers' articulation and visualization of actions through sketching and telling stories consisted of detailed, specific and rich understanding. Storytelling, such as depicting situations and contexts to compare work tasks and solve problems on the site, were essential to reveal and share tacit knowledge (Lensjø 2020; Polanyi 1966). The findings also show that linguistic interaction and reflections in and on action are in line with Schön's (2001) theory of practitioners' learning through reflective conversations about situations and contexts.

The apprentices confirmed their ability to plan, perform and complete the task not only by sketching or reading blueprints, but also through physically encountering objects and tools. By using their hands, gaining awareness of the strength and sensitivity of their fingers and recognizing smells and sounds, the apprentices gained access to multiple kinds of information. Our senses provide information that flows through our body. With the touch of a hand, the craftsman obtains meaningful information that leads to a spontaneous reaction or a logical conclusion (Sennett 2009). How our body and senses perceive things, space and time is especially prominent in Merleau-Ponty's (1994) comprehensive theory. Merleau-Ponty's phenomenology of the human body illuminates the empirical findings by pointing to the complexity in embodied learning and thus, to the necessity of doing and being, interacting and communicating as an active participant over time. The findings confirm that the individual's embodied perceptions of things and space are central in learning a craft, such as plumbing. Gamble (2006) deduces the timeconsuming process involved from understanding a sketch or a one-dimensional drawing and to creating the exact design or form in each material. In line with Gamble's study, the findings in this study emphasize that embodied perceptions require time - time to think, to visualize, to do and to fail, to be corrected, to try again and to succeed, repeatedly and variously. The apprentice's alternation between self-contained work tasks on the one hand and close guidance and collaboration with the plumbers and the TVET teacher on the other, seem to facilitate the apprentices' need for time to use their fingers and hands, trying out, doing and thinking while using their mind and their senses. Through each step of the learning process, the apprentices learn to use their whole body to work and to understand all parts and levels of their profession.

Knowing what to do and why means you are an active participant in your own life. The plumbers in this study emphasized the importance of not only doing - but also being able to influence their own work. According to Freire (2009), dialectical thinking is based on action and reflection, meaning that individuals should not act on another but instead, work with each other. A distinction between action and reflection prevents human dialog and according to Freire (2009), lies at the very heart of differentiation between groupings, class interests and oppression. In-depth training, between the

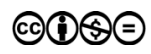


plumbers and the apprentices as well as between the apprentice and the TVET teacher, shows that active participation and liberating dialog are essential for job-satisfaction and learning outcomes.

\section{The intersection between Norwegian plumbers and migrant construction workers}

The empirical findings from the construction site tell a story of two very different groups working side by side on a daily basis: the small group of Norwegian training enterprises and the considerable larger group of foreign language-speaking, migrant construction workers. The intersection between these two groups shows several signs of a workplace that is deeply imbalanced. The plumbers' frustrations and uncertainty about what would appear the next day were often linked to language barriers and the migrants' longer working hours. Under these visible contradictions, however, hide power structures based on a shift from craft-centered to neo-Taylorist leadership principles (Friberg \& Haakestad 2020). This shift indicates that skilled work has been systematically deconstructed by emptying work tasks and processes of meaning and context, where the goal is to distribute the 'meaningful' work to the manager and the manual work to the working immigrants. Based on the unprecedented access to job-seeking east European migrants, manual workers have been easy to hire and replace. Today, the position of working immigrants in the Norwegian construction industry is reflected by short-term employment, lower wages and poor working conditions. The acquisition of skills and ownership of the craftsman's knowledge are indicators of the craftsman's status. Two important aspects of organization of work and organized vocational training are related to who owns the knowledge and how it is managed (Deichman-Sørensen 2015). How education and work are organized and maintained, thus are important expressions of social relations and of the balance of power in working life and in society. This study indicates that the large group of foreign language-speaking low paid workers in the Norwegian construction industry challenges the status and future of Norwegian craftcentered workers and thus, the TVET model.

Norway's participation in the European Economic Area (EEA) has influenced the education system in line with the Lisbon Treaty (2009) and the European goal to make the EU 'the world's most knowledge-based and competitive economy'. The purpose of the EU Qualifications Framework (EQF) is to develop standards for equal quality to compare and measure the level of education and knowledge and thus, to increase mobility within the EU's borders. Clarke and Winch (2006) indicate that an EU qualification comparator that fails to consider that 'qualification' has different usages in different languages will be extremely difficult, if not impossible, to implement unless a much clearer understanding of the different uses of terms is made available. Migrant workers' lack of language skills is a powerful barrier to comparing, measuring and thus, to utilizing their qualities and competences across linguistic borders (Kraft 2017). For construction workers, language and communication are issues that impact their safety and everyday work. One way to respond to linguistic diversity is to allocate work tasks to separate teams according to language, led by bilingual foremen. This process may give rise to a linguistically segregated working life, where natives and migrants work in different teams, holding different positions and performing different kinds of tasks 
according to linguistic background (Friberg \& Eldring 2013). Working conditions for different groups of eastern European workers working in the Norwegian construction industry vary considerably, but comprehensive research shows that they are exposed to different and poorer working conditions compared to Norwegian skilled workers working in the same industry (Friberg 2012, 2016). Despite the abuse of power expressed in this differing treatment of foreign labor, this study indicates that the organized regimes of labor migration also provide some benefits. From the migrants' point of view, it may be beneficial to negotiate work in their own language, so they do not have to spend time and money on learning the Norwegian language (Friberg 2012). In addition, the rotation system allows more work hours, which, in turn, allows migrants to travel between their workplace in Norway and their home country.

After nearly two decades of large-scale labor migration in the Norwegian construction industry, an increasing number of migrants have settled permanently in Norway (Friberg \& Eldring 2013). However, the findings in this small-scale study indicate that foreign construction workers prefer to join their compatriots during coffee and lunch breaks rather than their Norwegian colleagues, even if they have full-time permanent employment at a Norwegian company. This could be a sign of the group cohesion that can arise between workers in the same situation (Lysgaard 1961). Cohesion can develop strong bonds between the participants in the group. The sense of belonging to one group can make it very difficult to transition to another. Linguistic diversity can be a selfreinforcing factor in this context. This qualitative study represents few informants; thus, this finding should be investigated further. The large number of foreign construction workers working and living in parallel societies in Norway raises important questions that require more research. On one hand, parallel societies create obstacles to language learning, skills utilization and cooperation with and integration into Norwegian working life and society. On the other hand, this study shows that migrant workers' linguistic isolation, combined with long working hours in permanent rotation systems, excludes Norwegian construction workers from the necessary communication and cooperation on work and progress. Excluded from the dialog (Freire 2009) at the intersection between work and progress, the smaller group of Norwegian skilled workers was denied access to important information and participation. Exclusion and constant unpredictability at work caused weariness and challenged their work environment and job satisfaction. Systematic exclusion from the dialog inhibits the craftsman's traditions and knowledge, and puts skilled work and the TVET dual model under pressure.

\section{Conclusion}

In this study of training in the work-based part of Norwegian TVET, I examined a network of training enterprises and a plumbing training agency. Through interviews and one year of participatory fieldwork, I investigated how systematic collaboration in this network facilitated coherent training during the apprenticeship period. Considering the increased number of apprentices resulting from the statutory right to upper secondary education and thus, to the TVET programs, a shift was expected from master apprentice traditions toward instrumental forms of learning. What I found was a local professional network that organized pedagogical and coherent training in plumbing throughout the work-based part of TVET. In this article, I describe the apprentices'

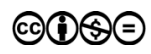


gradual development of responsible autonomy in the structured alternation between independent responsibility of peripheral plumbing tasks, close collaboration with skilled plumbers in central plumbing tasks and intensive collaboration with TVET teachers and apprentices in holistic, central plumbing tasks.

The analysis shows the complexity and the time-consuming process of developing and articulating intangible, embodied knowledge.

Despite the well-structured network and the priority given to training in the craftcentered, work-based part of TVET, the study also revealed recurring misunderstandings, errors and delays at the intersection between Norwegian training enterprises and the communities of migrant workers on the construction site. The study revealed traces of weariness within the community of Norwegian plumbers, as well as clear signs of erosion of skilled work on the construction site.

This article raises significant questions related to the ownership of vocational knowledge, considering the wide-ranging erosion of skilled work and thus, TVET training in the Norwegian construction industry. If skilled work and craftsmanship traditions systematically are fragmented and exported via temporary migrant construction workers, who will ultimately, be able to protect and maintain Norway's infrastructure and building heritage? The increasing dominance of male, foreign language-speaking construction workers at Norwegian construction sites, the implementation of longer work days, and the establishment of parallel societies challenge several key values, such as equality, inclusion and democracy in Norwegian working life and society. This study addresses tensions between values, and how values are challenged by neo-liberal trends emphasizing efficiency first and thus, subordinate democratic traditions. Measuring work in efficiency refers to economic values. The experience of security and meaning, codetermination and equality in working life refers to a value-based scale. The new labor division challenges the quality of the working conditions and raises questions about the future sustainability of the Norwegian VET model. I suggest that further research should seek to expand our understanding of the long-term effects of labor migration and the consequences for skilled work and Norwegian TVET.

\section{References}

Agrosino, M. V. \& Mays de Pères, K. A. (2000). Rethinking observation from Method to Context. In N. K. Denzin \& Y. S. Lincoln (Eds.), Handbook of Qualitative Research. pp. 673-702. 2nd edition, Thousand Oaks, California: Sage.

Alsos, K., Bråthen, M. \& Trygstad, S. C. (2016). Sjatteringer av likhet. Evaluering av reglene om likebehandling av utleid arbeidskraft[ Evaluation of the rules on equal treatment of hired labor]. Fafo-rapport 2016:15. https://www.fafo.no/images/pub/2016/20577.pdf. Accessed 10 October 2020.

Alvesson, M. \& Sköldberg, K. (2011). Tolkning och Reflektion [Interpretation and Reflection], Lund: Studentlitteratur AB.

Biernacki, R. (1995). The Fabrication of Labour: Germany and Britain 1640-1914, Berkeley: University of California Press. doi: http://dx.doi.org/10.2307/25144197.

Bravermann, H. (1977). Arbete och Monopolkapital. Arbeidets Degradering I Det Tjugonde Århundradet [Work and Money, Degradation of Work], Stockholm: Raben \& Sjøgren.

Brockmann, M., Clarke, L. \& Winch, C. (2008). Knowledge, skills, competence: European divergences in vocational education and training (VET) - the English, German and Dutch 
cases, Oxford Review of Education 34(5): 547-567. doi: http://dx.doi.org/10.4324/ 9780203814796.

Brown, J. S., Collins, A. \& Duguid, P. (1989). Situated cognition and the culture of learning. Educational Researcher 18(1): 32-42. doi: https://doi.org/10.21236/ada204690.

Cedefop (2011). Employment-related Mobility and Migration, and Vocational Education and Training, Working paper 9, Publications Office of the European Union. doi: http:// dx.doi.org/10.2801/38113.

Charmaz, K. (2014). Constructing Grounded Theory. 2nd edition, London: SAGE Publications Ltd.

Clarke, L. \& Winch, C. (2006). A European skills framework? - but what are skills? Anglo-Saxon versus German concepts, Journal of Education and Work 19(3): 255-268. doi: http://dx.doi.org/10.1080/13639080600776870.

Clarke, L., Winch, C. \& Brockmann, M. (2013). Trade-based skills versus occupational capacity: the example of bricklaying in Europe, Work, Employment and Society 27(6): 932-951. doi: http://dx.doi.org/10.1177/0950017013481639.

Corbin, J., \& Strauss, A. (1990). Grounded theory research: procedures, canons, and evaluative criteria, Qualitative Sociology 13(1): 3-21. doi: http://dx.doi.org/10.1007/bf00988593.

Deichman-Sørensen, T. (2015). Lik kvalitet - Fra yrkesstyring til ytrestyring, fra praksisfellesskap til fellesmarked [Equal quality - From professional management to external management, from community of practice to common market]. In O. Eikeland, H. Hiim \& E. Schwencke (Eds.), Yrkespedagogiske Perspektiver [Perspectives on Vocational Pedagogy]. pp. 219-257, Oslo: Gyldendal Norsk Forlag.

Dreyfus, H. \& Dreyfus, S. (2012). Fem stadier af færdighetdstilegnelse - fra nybegynder til ekspert [Skill acquisition]. In K. In Illeris (Ed.), 49 Tekster om Læring [49 Texts about Learning]. pp. 423-436), Fredriksberg C: Samfundslitteratur.

Education Act (1998). http://app.uio.no/ub/ujur/oversatte-lover/data/lov-19980717-061eng.pdf. Accessed 8 November 2020.

Eikeland, O. (2015). Om det allmenne ved yrkespedagogikken [General aspects of vocational Pedagogy]. In O. Eikeland, H. Hiim \& E.Schwencke (Eds.), Yrkespedagogiske Perspektiver [Perspectives on Vocational Pedagogy]. pp. 14-23. Oslo: Gyldendal Akademisk.

Evens, T. M. S. \& Handelman, D. (2005). The ethnographic praxis of the theory of practice, Social Analysis 49(3): 1-11. doi: http://dx.doi.org/10.3167/015597705780275075.

Freire, P. (2009). De undertryktes pedagogikk [Pedagogy of the Oppressed]. 2nd edition, Oslo: Gyldendal Norsk Forlag.

Friberg, H. J. (2012). The Polish Worker in Norway [Doctoral Thesis]. Institutt for sosiologi og samfunnsgeografi. University of Oslo. http://urn.nb.no/URN:NBN:no-33627, Accessed 15 October 2020.

Friberg, H. J. (2016). Arbeidsmigrasjon. Hva vet vi om konsekvensene for Norsk arbeidsliv, Samfunn og økonomi? [Labor migration. What do we know about the consequences for Norwegian work life, society and economy?] Fafo-rapport 2016:2. doi: http://dx.doi. org/10.13140/RG.2.2.17014.19526.

Friberg, H. J. (2016). The rise and implications of temporary staffing as a migration industry in Norway, Nordic Journal of Migration Research 6(2): 81-91. doi: http://doi. org/10.1515/njmr-2016-0013.

Friberg, H. J. \& Haakestad, H. (2020). Deskilling revisited: Labour migration, neoTaylorism and the degradation of craft work in the Norwegian construction industry, Economic and Industrial Democracy 2020; 41(3): 630-651. doi: http://dx.doi. org/10.1177/0143831X17735671.

Gamble,J.(2001). Modelling the invisible: the pedagogy of craft apprenticeship, Studies in Continuing Education 23(2): 185-200, doi: http://dx.doi.org/10.1080/01580370120101957. 
Geertz, C. (1973). The Interpretation of Cultures, New York: Basic Books.

Giddens, A. (1993). New Rules of Sociological Method: A Positive Critique of Interpretative Sociologies, Cambridge: Polity Press.

Glaser, B. G. \& Strauss, A. L. (1967). The Discovery of Grounded Theory: Strategies for Qualitative Research, Chicago: Aldine Transaction.

Gluckman, M. (1959). Custom and Conflict in Africa, Glencoe: Free Press.

Gluckman, M. (1961). Ethnographic data in British social anthropology, Sociological Review 9(1): 5-17. doi: https://doi.org/10.1111/j.1467-954x.1961.tb01082.x.

Hall, P. \& Soskice, D. (2001). Varieties of Capitalism: The Institutional Foundations of Comparative advantage, Oxford: Oxford University Press.

Hastrup, K. (2010). Feltarbejde [Fieldwork]. In SBrinkmann \& L. Tanggaard (Eds.), Kvalitative Metoder [Qualitative Methods]. pp. 55-80], Copenhagen: Hans Reitzels Forlag.

Illeris, K. (2006). Læring [Learning], Roskilde: Roskilde Universitetsforlag.

Illeris, K. (2010). The Fundamentals of Workplace Learning: Understanding How People Learn in Working Life. Routledge. doi: http://dx.doi.org/10.4324/9780203836521.

Ilsøe, A., Larsen, T. P. \& Rasmussen, S. (2019). Precarious work in the Nordics: introduction to the theme of the special issue, Nordic Journal of Working Life Studies 9(S6): doi: https://doi.org/10.18291/njwls.v9iS6.114688.

Kalleberg, A. L. (2000). Nonstandard employment relations: part-time, temporary and contract work, Annual Review of Sociology 26(1): 341-365. doi: http://dx.doi.org/10.1146/ annurev.soc.26.1.341.

Kraft, K. (2017). Constructing Migrant Workers: Multilingualism and Communication in the Transnational Construction Site [Doctoral thesis], University of Oslo, Faculty of Humanities.

Lave, J. \& Wenger E. (1991). Situated Learning. Legitimate Peripheral Participation, København: Hans Reitzels Forlag.

Lensjø, M. (2020). Stories of Learning: A Case Study of Norwegian Plumbers and Apprentices in TVET at the Construction Site and in a Training Agency. International Journal for Research in Vocational Education and Training.7(2): 148-166. doi: https://doi. org/10.13152/IJRVET.7.2.2.

Lysgaard, S. (1961). Arbeiderkollektivet - En Studie I de Underordnedes Sosiologi [The Working-Class Collective. A Study in the Sociology of Subordinates]. pp. 226-258, Oslo: Universitetsforlaget.

Marsden, D. (1999). A Theory of Employment Systems: Microfoundations of Societal Diversity, Oxford: Oxford University Press.

Merleau-Ponty, M. (1994). Kroppens fenomenologi [The Phenomology of the Body]. Taylor and Frances e-library (2005).

Nielsen, K. \& Kvale, S. (1999). Mesterlære. Læring som Sosial Praksis [Master-Apprentice Model. Learning as a Social Practice], Oslo: Ad Notam Gyldendal AS.

Norwegian Directorate for Education and Training. (2020). Core Curriculum - Values and Principles for Primary and Secondary Education. https://www.udir.no/lk20/overordnet-del/?lang=eng, Accessed 3 Martz 2021.

Nyen, T. \& Tønder, A. H. (2015). Cooperation and reform in vocational education and training. In F. Engelstad \& A. Hagelund (Eds.), Cooperation and Conflict the Nordic Way. pp. 201-217, Oslo: Institute for Social Research. doi: http://dx.doi.org/10.1515/9783110436891-012.

OECD (2014). International Migration Outlook 2014, OECD Publishing. doi: http://dx.doi. org/10.1787/migr outlook-2014-en.

Official Journal of the European Union. (2016). Consolidated reader-friendly edition of the Treaty on European Union (TEU) and the Treaty on the Functioning of the European Union (TFEU) as amended by the Treaty of Lisbon (2007). Foundation for EU Democracy. https://eur-lex.europa.eu/legal-content/EN/TXT/PDF/?uri=CELEX:12016E/ TXT\&from=EN, Accessed 4 December 2020. 
Olsen, O. J., Høst, H. \& Michelsen, S. (2008). Veier fra yrkesopplæring til arbeidsliv. En studie av det norske overgangsregimets effektivitet [From VET to work]. In J. Olofsson \& A. Panican (Eds.), Ungdomars väg fran skola till arbetsliv. Nordiska erfarenheter [Young people's path from school to work-life]. pp. 249-332. TemaNord 2008:584, Copenhagen: Nordisk Ministerråd. doi: http://dx.doi.org/10.6027/TN2008-584.

Olsen, O. J., Thunqvist, D. P. \& Hallqvist, A. (2018). Building and construction. A critical case for the future of vocational education. In C. H. Jørgensen, O. J. Olsen, \& D. P. Thunqvist (Eds.), Vocational Education in the Nordic countries. pp. 136-155. New York: Routledge.

Polanyi, M. (1966). The Tacit Dimension, London: Routledge \& Kegan.

Rauner, F. (2004). Praktisches Wissen und berufliche handlingskompetenz. ITB Forschungsberichte 14 [Practicle knowledge and professional skills], Bremen: University of Bremen. https://www.ssoar.info/ssoar/bitstream/handle/document/36604/ssoar-2004-raunerPraktisches Wissen und berufliche Handlungskompetenz.pdf? sequence=1 \& is Allowed=y\&lnkname=ssoar-2004-rauner-Praktisches Wissen und berufliche Handlungskompetenz.pdf, Accessed 18 March 2021.

Reegård, K. \& Rogstad, J. (2019). Track-VET: Developing, Assessing and Validating Transversal Key Competences in the Formal and Continuing Vet. Country Report Norway - Final Version, 2019. Erasmus+ Project, Fafo. http://www.track-vet.eu/system/files/Country\% 20report \%20Norway \%2010\%202019\%20final.pdf, Accessed 10 October 2020.

Ringer, A. (2013). Researcher-participant positioning and the discursive work of categories: experiences from fieldwork in the mental health services, Journal of Qualitative Studies 4(1): 1-20. doi: http://dx.doi.org/10.7146/qs.v4i1.8126.

Ryan, L., Lavelle, J., O’Sullivan, M., McMahon, J., Murphy, C., Turner, T., Gunnigle, P., \& O'Brian, M. (2019). Defining and regulating zero-hours work: lessons form a liberal market economy, Nordic Journal of Working Life Studies 9(S6): doi: http://dx.doi. org/10.18291/njls.v9is6.114692.

Schön D. A. (2001). The Reflective Practitioner - How Professionals Think in Action, Århus: Forlaget Klim.

Sennett, R. (2009). The Craftsman, London: Penguin Books Ltd.

Statistics Norway (2019). Arbeidsinnvandringen øker Igjen [Increasing Labor Migration]. https://www.ssb.no/befolkning/artikler-og-publikasjoner/flest-innvandrer-pa-grunnav-arbeid, Accessed 20 November 2020.

Steen, J. R., Oldervoll, J., Walbækken, M. M. \& Røtnes, R. (2018). Fagarbeideres og fagopplæringens betydning for innovasjon [The Importance of Skilled Workers and TVET for Innovation]. Fafo rapport 2018: 14. https://www.fafo.no/images/pub/2018/20663.pdf, Accessed 1 December 2020.

Stinchcombe, A. L. (1959). Bureaucratic and craft administration of production: a comparative study, Administrative Science Quarterly 4(2): 168-187. doi: http://dx.doi. org/10.2307/2390676.

Van der Geest, S. \& Sarkodie, S. (1998). The fake patient. A research experiment in a Ghanaian Hospital, Social Science \& Medicine 47(9): 1373-1381. doi: http://dx.doi.org/10.1016/ s0277-9536(98)00179-8.

Wadel, C. (2016). Feltarbeid I Egen Kultur [Fieldwork in One's Own Culture], Oslo: akademisk@cappelendamm.

Wenger, E. (1998). Communities of Practice. Learning, Meaning and Identity, Cambridge University Press.

Working Environment Act (2005). https:/lovdata.no/dokument/NLE/lov/2005-06-17-62. Accessed 5 December 2020.

Ødegård, A. M., Berge, Ø. \& Alsos, K. (2012). A case study of temporary work agencies in the Norwegian construction sector, European Review of Labour and Research 18(4): 461-470. doi: http://dx.doi.org/10.1177/1024258912458875. 